\title{
OmpA signal peptide leads to heterogenous secretion of $B$. subtilis chitosanase enzyme from E. coli expression system
}

\author{
Phornsiri Pechsrichuang ${ }^{1}$, Chomphunuch Songsiriritthigul' ${ }^{2}$, Dietmar Haltrich ${ }^{3}$, Sittiruk Roytrakul ${ }^{4}$, \\ Peenida Namvijtr ${ }^{1}$, Napolean Bonaparte ${ }^{1}$ and Montarop Yamabhai ${ }^{*}$ (i)
}

\begin{abstract}
The production of secreted recombinant proteins from E. coli is pivotal to the biotechnological industry because it reduces the cost of downstream processing. Proteins destined for secretion contain an $\mathrm{N}$-terminal signal peptide that is cleaved by secretion machinery in the plasma membrane. The resulting protein is released in an active mature form. In this study, Bacillus subtilis chitosanase (Csn) was used as a model protein to compare the effect of two signal peptides on the secretion of heterologous recombinant protein. The results showed that the E. coli secretion machinery could recognize both native bacillus and E. coli signal peptides. However, only the native bacillus signal peptide could generate the same $\mathrm{N}$-terminal sequence as in the wild type bacteria. When the recombinant $\mathrm{Cs}$ constructs contained the E. coli OmpA signal peptide, the secreted enzymes were heterogeneous, comprising a mixed population of secreted enzymes with different N-terminal sequences. Nevertheless, the E. coli OmpA signal peptide was found to be more efficient for high expression and secretion of bacillus Csn. These findings may be used to help engineer other recombinant proteins for secretory production in E. coli.
\end{abstract}

Keywords: Secretion, Recombinant, E. coli, Expression, Signal peptide, OmpA, Bacillus, Chitosanase

\section{Background}

The production of secreted recombinant proteins from E. coli is pivotal to the biotechnological industry because it reduces the cost of downstream processing associated with non-secreted proteins (Mergulhao et al. 2005). Secreted proteins are usually properly folded and more stable than cytosolic protein because of lower protease levels in the periplasm or culture medium. Proteins destined for secretion carry an $\mathrm{N}$-terminal signal peptide that is cleaved in the plasma membrane by different mechanisms. The resulting protein is released in an active mature form (Mergulhao et al. 2005). E. coli is the

\footnotetext{
*Correspondence: Montarop@g.sut.ac.th; montarop@sut.ac.th ${ }^{1}$ Molecular Biotechnology Laboratory, School of Biotechnology, Institute of Agricultural Technology, Suranaree University of Technology (SUT), 111 University Avenue, Meung District, Nakhon Ratchasima 30000, Thailand Full list of author information is available at the end of the article
}

most commonly used cell factory for the expression and secretion of recombinant enzymes and other biologically active proteins (Mergulhao et al. 2005).

Since secreted recombinant proteins are fused with an E. coli signal peptide, the cleavage site is often unknown and hard to predict because it does not have to be the same as for the natural protein. This trivial issue can have a significant effect on biological activity and protein expression. Despite the importance of this aspect of protein engineering for secretion, there have been only a few reports on the effect of signal peptides on protein expression and subsequent processing in E. coli. The aim of this study was to investigate the effect of two different signal peptides on recombinant protein expression and N-terminal processing using chitosanase (Csn) from Bacillus subtilis as a model protein. This enzyme is biotechnologically important because it converts chitosan, 
a recalcitrant waste product from the seafood industry, into value-added chito-oligosaccharides (CHOS), which have been shown to have excellent health and agricultural benefits (Pechsrichuang et al. 2013; Zhou et al. 2015). It is a relatively small, $28-\mathrm{kDa}$ extracellular enzyme that is secreted from Bacillus subtilis, a Grampositive bacteria (Pechsrichuang et al. 2013). To analyze the effect of different signal peptides, a gene encoding mature Csn together with its native signal peptide and a gene encoding recombinant $C s n$ with its native signal peptide replaced with OmpA, a signal peptide from the Gram-negative bacteria E. coli, were cloned into a Ptacbased expression vector and over-expressed in E. coli TOP10 cells (Fig. 1). Protein expression levels and enzymatic activity at different time points, in various compartments, and the sequence of the $\mathrm{N}$-terminus of the secreted proteins were determined.

In this article, we show that the type of signal peptide can affect both the structure of the $\mathrm{N}$-terminus and the expression level of recombinant proteins that are secreted from an $E$. coli expression system.

\section{Results}

\section{Cloning and secretion of recombinant Csn containing two} different signal peptides on agar plates

The $t a c$ promoter was used to control the expression of the two recombinant Csn forms, and protein over-expression was induced with IPTG. The recombinant enzymes were fused with $10 \times$ histidine tags at the C-termini to facilitate one-step affinity purification using IMAC, which allowed for accurate determination of production yield and the sequence of $\mathrm{N}$-terminal amino acids.

For the Nat-Csn construct, the native Bacillus signal peptide (35 amino acids) was retained by cloning the entire B. subtilis Csn gene into the pMY202 vector, which had been previously digested with NdeI and BglII. The PCR products ( $831 \mathrm{bp})$ were digested with NdeI and $B g l \mathrm{II}$ and cloned into corresponding restriction sites on the pMY202 plasmid (Fig. 1, left panel). For the OmpA-Csn construct, the native signal peptide of B. subtilis Csn was replaced with that of the E. coli OmpA signal peptide. The PCR products ( 726 bp) were digested with HindIII and BamHI and cloned into corresponding restriction sites on the pMY202 plasmid, which contained the OmpA gene. This resulted in the fusion of the E. coli OmpA signal peptide with the mature enzyme (Fig. 1, right panel). The DNA sequences of the two constructs were confirmed by automated DNA sequencing (Macrogen, Korea). The theoretical molecular mass of the Nat-Csn and OmpA-Csn constructs were 33.23 and $31.26 \mathrm{kDa}$, respectively.

To compare the effect of the signal peptide on Csn secretion on agar plates, a single colony of $E$. coli TOP10 harboring pMY202 containing either OmpA-Csn or NatCsn was grown on LB-Amp agar containing $0.1 \%$ low MW chitosan, and $0,0.1$ or $0.5 \mathrm{mM} \mathrm{IPTG}$, and incubated at $37{ }^{\circ} \mathrm{C}$. Clearing zones from different conditions were measured at different time points and plotted as shown in Fig. 2, left panel. Representative clearing zones are shown on the right panel. While no clearing zones were
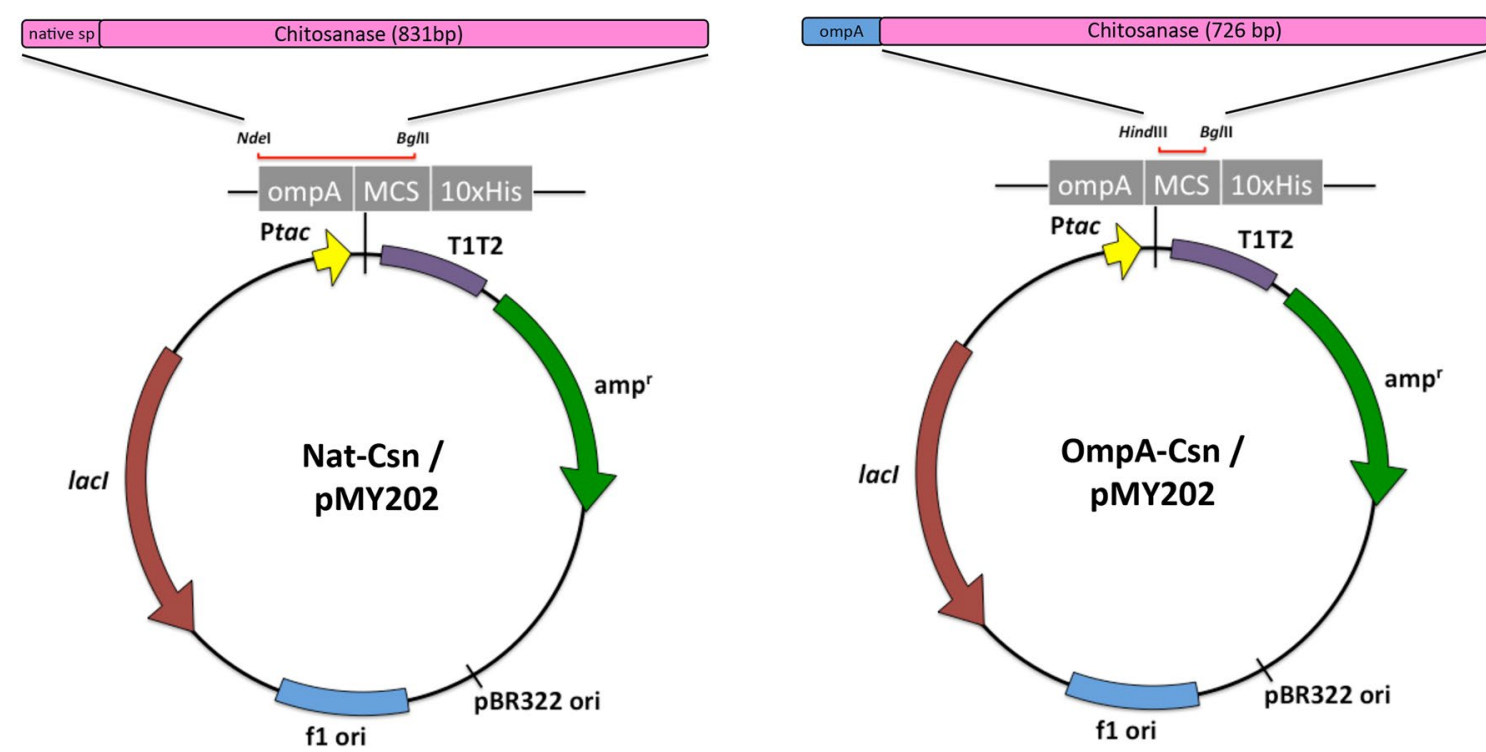

Fig. 1 Map of constructs used in this study. Nat-Csn (construct on left) was used for secretory expression of Csn via its native bacillus signal peptide, while OmpA-Csn (construct on right), comprised of the mature enzyme fused with the E. coli OmpA signal peptide that is a component of the pMY202 vector 

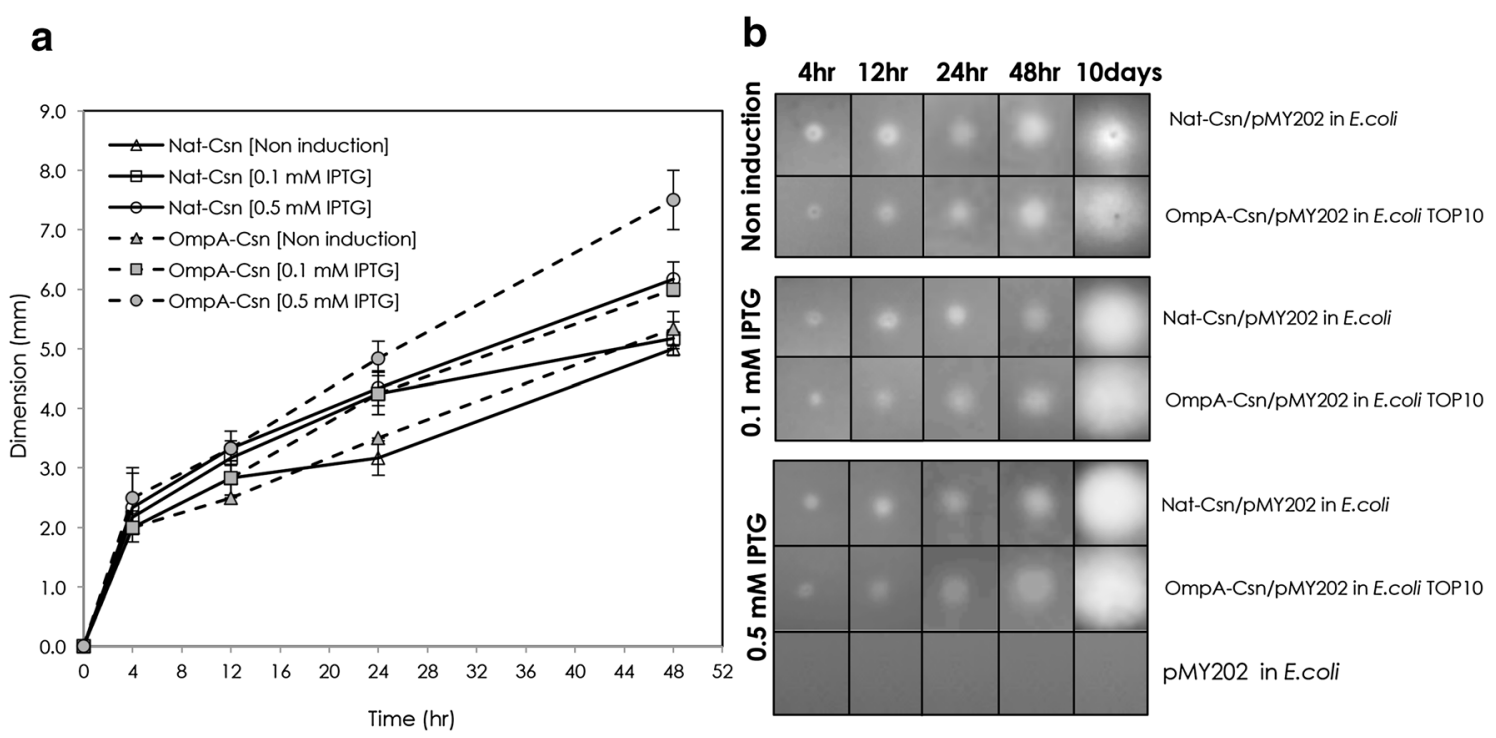

Fig. 2 Secretion of recombinant Csn. Mean clear zones diameters (from three colonies of E. coli expressing recombinant Nat-Csn and OmpA-Csn) at $0,4,12,24$, and $48 \mathrm{~h}$ are shown in the panel $\mathbf{a}$ along with standard error. Representative clear zones from different conditions at 4, 12, 24, 48, and 10 days are shown in the panel $\mathbf{b}$. No clear zone was detected around colonies of E. coli expressing empty vector (bottom row). Enlarged picture of the clear zones can be found in Additional file 1: 56

observed in E. coli expressing empty vector, the size of clearing zones of $E$. coli expressing OmpA-Csn were significantly larger than those from Nat-Csn-expressing $E$. coli after $48 \mathrm{~h}$. These results suggest that homologous OmpA is more efficient than the native signal peptide at directing the secretion of heterologous enzyme in E. coli. Moreover, these results indicated that over-expression of ptac promoter could be induced by increasing concentration of IPTG. The observation of clear zones in the absence of IPTG was an indication that the promoter was leaky.

\section{Effect of signal peptides on yield and secretion efficiency of recombinant Csn containing two different signal peptides in an $E$. coli expression system}

To further evaluate the effect of the signal peptides on the expression and secretion of Csn from E. coli, the recombinant proteins were collected from three different compartments (cytoplasm, periplasmic space, and culture broth) and their enzyme activities were analyzed at different time points.

The total enzyme activity in the compartments and the secretion efficiency at different time points are reported in Table 1. These results indicate that the yield of the construct containing the E. coli signal peptide was approximately twofold to tenfold higher than the yield of constructs with the native signal peptide, but was dependent on induction time and compartment. At $20 \mathrm{~h}$ after induction, both total yield and secretion efficiency of constructs with the OmpA signal peptide were approximately twofold higher than those with the native signal peptide. Moreover, the enzyme activities in the periplasm and culture broth were both approximately fivefold higher when OmpA was used as the signal peptide. At $4 \mathrm{~h}$ after induction, when periplasmic leakage should be insignificant (Albiniak et al. 2013; Rinas and Hoffmann 2004), the use of the OmpA signal peptide resulted in as much as a tenfold higher Csn activity in the periplasm. The differences in yield and secretion efficiency were not observed at time 0 , when the gene expression was not induced by IPTG. However, leaky expression from the tac promoter could be observed as shown in an assay on agar plates. Under these conditions, the secretion efficiency of constructs containing either the E. coli or the native signal peptide was equally high.

To accurately determine the yield and activity of recombinant Csn, secreted enzymes were purified from culture broth to homogeneity (Fig. 3a, b). The expected size of secreted recombinant Csn was approximately $32 \mathrm{kDa}$. The SDS-PAGE analysis of crude secreted enzymes from culture broth or cell lysate (periplasm plus cytosol) are illustrated in Fig. 3c. Routinely, approximately 18.5 and $0.4 \mathrm{mg} / \mathrm{L}$ of purified OmpA-Csn and Nat-Csn could be purified from culture supernatant of shake-flask cultivation, respectively (see Additional file 2: S7 for purification table). Both purified recombinant Csn proteins had specific activities of approximately $650 \mathrm{U} / \mathrm{mg}$. These results are consistent with previous results on agar plates that 
Table 1 Enzyme activity and secretion efficiency

\begin{tabular}{|c|c|c|c|c|}
\hline & \multirow[t]{2}{*}{$\begin{array}{l}\text { Induction } \\
\text { time (h) }\end{array}$} & \multicolumn{2}{|c|}{$\begin{array}{l}\text { Enzymatic activity (total } \\
\text { units) }\end{array}$} & \multirow[t]{2}{*}{ Fold change $^{b}$} \\
\hline & & Native Sp & OmpA Sp & \\
\hline \multirow[t]{3}{*}{ Broth } & 0 & $85.5 \pm 2.00$ & $98.0 \pm 2.92$ & 1.15 \\
\hline & 4 & $115 \pm 1.5$ & $244 \pm 5.1$ & 2.12 \\
\hline & 20 & $265 \pm 2.0$ & $1386 \pm 2.6$ & 5.23 \\
\hline \multirow[t]{3}{*}{ Periplasm } & 0 & $0.93 \pm 0.02$ & $0.99 \pm 0.01$ & 1.06 \\
\hline & 4 & $2.03 \pm 0.01$ & $22.2 \pm 0.20$ & 10.9 \\
\hline & 20 & $4.90 \pm 0.09$ & $27.6 \pm 0.69$ & 5.63 \\
\hline \multirow[t]{3}{*}{ Cytosol } & 0 & $21.3 \pm 0.02$ & $20.5 \pm 0.35$ & 0.96 \\
\hline & 4 & $388 \pm 2.6$ & $561 \pm 12.8$ & 1.45 \\
\hline & 20 & $528 \pm 5.1$ & $564 \pm 0$ & 1.07 \\
\hline \multirow[t]{3}{*}{ Total } & 0 & $108 \pm 2.0$ & $119 \pm 3.3$ & 1.10 \\
\hline & 4 & $505 \pm 1.2$ & $828 \pm 7.5$ & 1.64 \\
\hline & 20 & $798 \pm 3.0$ & $1978 \pm 3.2$ & 2.48 \\
\hline Secretion & 0 & $79.3 \pm 0.39$ & $82.0 \pm 0.21$ & 1.03 \\
\hline Efficiency & 4 & $22.7 \pm 0.34$ & $29.5 \pm 0.88$ & 1.30 \\
\hline$(\%)^{c}$ & 20 & $33.2 \pm 0.38$ & $70.1 \pm 0.01$ & 2.11 \\
\hline
\end{tabular}

Expression and secretion of $B$. subtilis $C$ sn into different compartments of the E. coli host harboring Nat-Csn/pMY202 or OmpA-Csn/pMY202, which contain native (Native Sp) or OmpA (OmpA Sp) signal peptides

a Total enzyme activity from $50 \mathrm{~mL}$ culture. The experiments were done in duplicate and the average values with standard deviations are reported. The enzyme was induced for over expression with $0.5 \mathrm{mM}$ IPTG

${ }^{b}$ Fold change indicates the relative values of the yields or secretion efficiencies of constructs with different signal peptides from different compartments (OmpA Sp divided by native $\mathrm{Sp}$ )

c Secretion efficiency was calculated from the percentage of the enzyme activity from culture broth plus periplasmic space divided by the total enzyme activities from all three compartments

the OmpA signal peptide is not only more efficient at directing recombinant Bacillus Csn secretion via the Secdependent pathway in an $E$. coli expression system, but it also allows for increased protein expression upon induction with IPTG.

\section{$\mathrm{N}$-terminal sequencing of secreted recombinant Csn}

When proteins are secreted via the $E$. coli secretory pathway, the signal peptide is cleaved by membranebound signal peptidases before the mature enzyme is released into the extracellular environment (Choi and Lee 2004). Since most recombinant proteins are foreign to $E$. coli, the cleavage sites can be predicted (Bendtsen et al. 2004; Zhang and Henzel 2004) but may differ from the actual cleavage sites that are often unknown. The secreted recombinant $\mathrm{Csn}$ were subjected to $\mathrm{N}$-terminal sequencing to investigate whether changes in the structure of signal peptide could lead to alterations in amino acid sequence at the $\mathrm{N}$-terminus. To do this, secreted enzymes were purified from culture broth, transferred onto PVDF (Fig. 3d) and submitted for N-terminal sequencing. The raw $\mathrm{N}$-terminal sequencing data can be found in Additional file 3: S2, Additional file 4: S3, Additional file 5: S4 and Additional file 6: S5. Interestingly, our results indicated that the native signal peptide was cleaved homogenously at the expected site (see Additional file 3: S2, Additional file 4: S3), as indicated by an arrow in Fig. 4, top panel. However, when the OmpA signal peptide was used, the secreted enzyme was found to be in a heterogeneous population, whereby the signal peptide was cleaved at three different sites (see Additional file 5: S4, Additional file 6: S5). One of these sites was the predicted site for the OmpA signal peptide; however, none of these sites yielded the correct mature, native Bacillus enzyme (which should start at AGLN).

\section{MALDI-TOF mass spectrometry of secreted recombinant Csn}

To confirm and further analyze the heterogeneous population of Csn secreted via the OmpA signal peptide, purified secreted Csn-OmpA protein was subjected to MALDI-TOF-MS for determination of intact molecular mass. Two intense mass signals corresponding to 30,339.71 and 31,150.36 Da were detected (Fig. 5). The $\mathrm{m} / \mathrm{z}$ ratio of these two signals corresponded well with amino acids 13-287 (cleavage site 1) and 22-287 (cleavage site 2), which encode proteins that are 275 and 266 amino acids, respectively. These mass determinations for purified Csn-OmpA were consistent and reproducible following several separate experiments. Since the sensitivity of MALDI TOF-MS is in the femtogram range, therefore, we could only confirm the presence of two heterogeneous products of secreted bacillus Csn using the OmpA signal peptide. Taken together these results indicated that even though the OmpA signal peptide could efficiently direct the secretion of the recombinant protein, the site of signal peptide cleavage might not have been accurate, resulting in a heterogeneous population of secreted proteins. In addition, our data indicated that the secretory machinery and the N-terminal signal peptidases of Gram-negative E. coli and Gram-positive Bacillus are highly similar, even if the structure of their cell walls are significantly different, because the $E$. coli translocation machinery could efficiently process and transport native Bacillus enzyme with native signal peptide.

\section{Discussion}

Despite a substantial amount of information about secretion mechanisms, types of signal peptides and the effect of signal peptides on the secretion of different enzymes in various expression systems (Degering et al. 2010; Mathiesen et al. 2008; Nakamura et al. 1989), little information on the structure of the N-termini of the secreted recombinant proteins in $E$. coli has been reported. Even though many online databases and software programs 


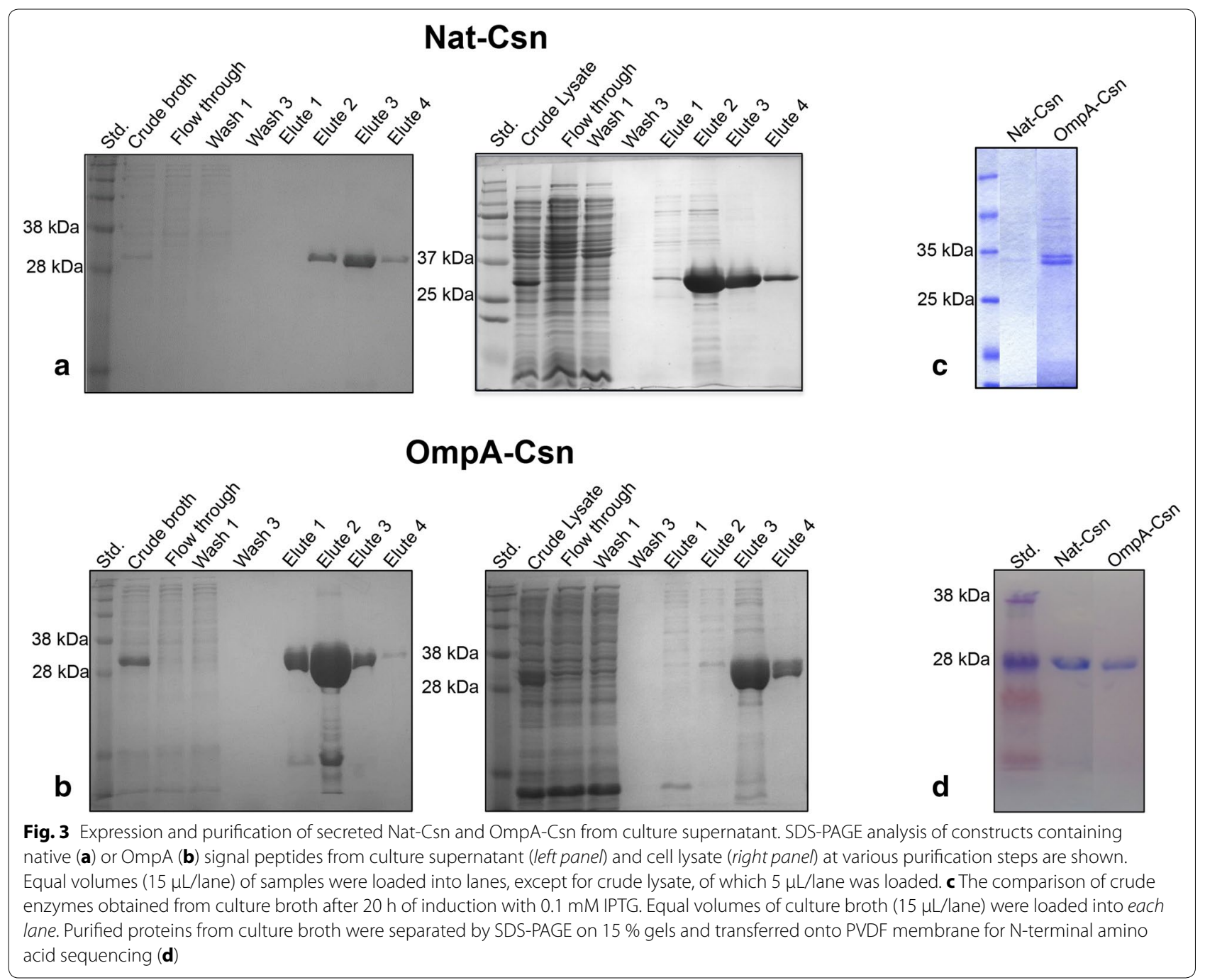

can be used to predict signal peptides and cleavage sites, these algorithms are not always accurate (Zhang and Henzel 2004), as demonstrated in this study.

It has been previously shown that in addition to the signal peptide, the protein domain adjacent to the signal sequence, called the export initiation domain, is critical for protein translocation across the inner membrane of $E$. coli (Andersson and von Heijne 1991). Bacillus Csn was selected as a model in this study because it is an extracellular enzyme and therefore contains an export initiation domain that favors secretion. As such, Bacillus Csn was well suited for the purpose of this study, where mainly the effect of the signal peptide was compared.

While native Bacillus signal peptide can be recognized by $E$. coli secretion machinery, the secretion efficiency was not as high as when the OmpA signal peptide was used. In the presence of the Bacillus signal peptide, the secretion efficiency was $33.8 \%$ at $20 \mathrm{~h}$ after induction, indicating that two-thirds of the recombinant proteins were retained in the cell. However, the $\mathrm{N}$-terminal signal peptide had identical cleavage sites as in native Bacillus strains, indicating that $\mathrm{N}$-terminal signal peptide processing is very accurate. This result indicates that both E. coli OmpA and native Bacillus Csn signal peptides direct the export of proteins via similar Sec-dependent secretion machinery. In addition, our data suggests that Bacillus and E. coli signal peptidases are functionally similar, even though their cell wall structures are very different. These data support the previous observation that the major components of the Sec machinery, which are required for protein secretion in both Bacillus and E. coli, are quite similar (Yuan et al. 2010).

Both gram-positive and gram-negative employ a similar type I signal peptidase (SPase), a membrane-bound 


Nat-CSn
MKISMQKADFWKKAAISLLVFTMFFTLMMSETVFA AGLNKDQKRRAEQLTSIFENGT
TEIQYGYVERLDDGRGYTCGRAGFTTATGDALEVVEVYTKAVPNNKLKKYLPELRRL
AKEESDDTSNLKGFASAWKSLANDKEFRAAQDKVNDHLYYQPAMKRSDNAGLKTALA
RAVMYDTVIQHGDGDDPDSFYALIKRTNKKAGGSPKDGIDEKKWLNKFLDVRYDDLM
NPANHDTRDEWRESVARVDVLRSIAKENNYNLNGPIHVRSNEYGNFVIKGSVDHHHH
HHHHHHLDYKDDDDK

OmpA-Csn \begin{tabular}{|l|l|}
\hline 2 & 3 \\
\hline
\end{tabular}

MKKTAIAIAVALAGFATVAQASAGLNKDQKRRAEQLTS IFENGTTEIQYGYVERLDD GRGYTCGRAGFTTATGDALEVVEVYTKAVPNNKLKKYLPELRRLAKEESDDTSNLKG FASAWKSLANDKEFRAAQDKVNDHLYYQPAMKRSDNAGLKTALARAVMYDTVIQHGD GDDPDSFYALIKRTNKKAGGSPKDGIDEKKWLNKFLDVRYDDLMNPANHDTRDEWRE SVARVDVLRS IAKENNYNLNGPIHVRSNEYGNFVIKGSVDHHHHHHHHHHLDYKDDD DK

Fig. 4 Signal peptide cleavage sites. N-terminal sequencing of Nat-Csn and OmpA-Csn was performed by Edman degradation on an Applied Biosystems Procise 492 protein sequencer. Arrows indicate cleavage sites. Native and OmpA signal peptides are underlined. The first amino acid after the underline is the predicted cleavage site. The amino acid sequences obtained from the N-terminal analysis are highlight in yellow. For NatCsn the sequence was AGLNK; while the three sequences from OmpA-Csn were SAGLN (site 2), GLNKD (site 3), and AGFAT (site 1). Two short bars the overlapped between site 2 and 3

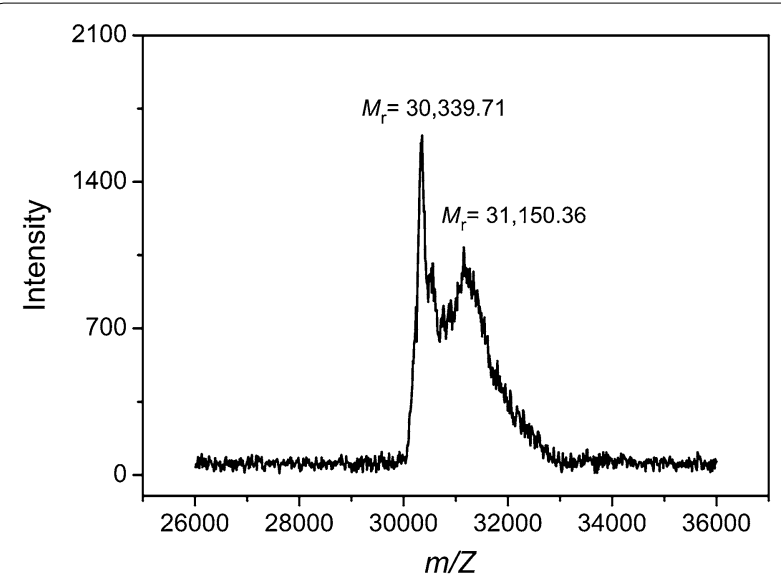

Fig. 5 MALDI-TOF MS analysis of the recombinant OmpA-Csn. Two mass signals with molecular mass (m/z) of 30,339.71 and 31,150.36 Da as measured in a linear positive mode were indicated. Bovine insulin, equine cytochrome $C$, and equine apomyoglobin were used as external calibrated standard

endopeptidase, to remove the signal peptide from exported pre-enzymes during the late stages of the transport process (Paetzel 2014; van Roosmalen et al. 2004). The consensus SPase recognition sequence is Ala-X-Ala at positions- 1 and -3 relative to the cleavage site in preproteins (Paetzel 2014). B. subtilis proteomics analysis revealed that $71 \%$ of the corresponding signal peptides contain the consensus Ala-X-Ala recognition sequence; while $18 \%$ of the identified extracellular proteins contain a Val-X-Ala recognition sequence (van Roosmalen et al. 2004). Therefore, native Bacillus SP could be cleaved precisely after VFA sequence, generating precise $\mathrm{N}$-terminus as indicated in Fig. 4. As for construct containing OmpA signal peptide, there were two Ala-XAla sequences, which was artificially created by genetic engineering, consequently we detected two cleavage sites after the two Ala-X-Ala sequences (cleavage site 2 and 3 ). The cleavage site 1 was unusual as it was situated in the middle of hydrophobic region of signal peptide, before a helix-breaking glycine residue. This cleavage might have occurred via a different secretory pathway due to the incompatibility between the export initiation domain of Bacillus Csn and Gram-negative OmpA signal peptide. This result suggested that, one should avoid creating more than one Ala-X-Ala sequence at the junction between signal peptide and mature protein, when engineering a recombinant protein for secretory production.

The two signal peptides had significantly different effects on the secretory production of recombinant proteins in E. coli. As shown in Table 1, the OmpA signal peptide led to significantly higher yields of recombinant enzyme, compared with the native signal peptide. Codon optimization analysis, using OPTIMIZER, an 
online application for improving expression levels, indicated that the codon adaptation index (CAI) based on codon usage of predicted highly expressed genes of the $\mathrm{N}$-terminus of the native Bacillus signal peptide, was only 0.537 (1.0 is the highest) (Puigbo et al. 2007). Therefore one explanation for the higher expression yield could be because the codon of the homologous OmpA sequence located at the $5^{\prime}$ end of the gene is more compatible with the $E$. coli translation machinery, especially at the initiation of translation step. Further study by codon optimization of native Csn signal peptide to mimic the codon usage of $E$. coli will be necessary to test if this could help improve expression levels without compromising the fidelity of signal peptide cleavage. If successful, this may have broader commercial applications in the future.

It is interesting to note that the ptac promoter was leaky (de Boer et al. 1983), resulting in low protein expression in the absence of induction with IPTG. At this low expression level, both signal peptides had $80 \%$ secretion efficiency. It is possible that the secretion machinery was not fully occupied and still able to process the secretion of both signal peptides (Driessen et al. 2001). However, when IPTG was used to induce protein over-expression, secretion mediated by the native Bacillus signal peptide, which was less compatible with the $E$. coli translocase complex, became the rate-limiting step for secretory production much earlier than when OmpA was used (de Keyzer et al. 2003). Another possibility is that the signal peptides used different secretion pathways (Muller et al. 2001). Recently, it was shown that a short peptide could serve as a signal peptide and guide heterologous cellulose proteins across both the inner and outer membranes of E. coli (Gao et al. 2015). Taken together these results suggest that when the $\mathrm{N}$-terminal sequence of a protein is not critical, the OmpA signal peptide is preferred for the secretion of recombinant proteins in $E$. coli-based systems.

\section{Conclusions}

Our results indicated that in an E. coli expression system, the E. coli OmpA signal peptide was more efficient than the native Bacillus signal peptide, for both expression and secretion of Bacillus Csn; however, cleavage of the signal peptide was not precise. Moreover, our results also indicated that the secretion machinery of Gram-negative $E$. coli could be used to correctly process the signal sequence and efficiently direct the secretion of extracellular hydrolytic enzymes from Gram-positive bacteria, despite significant differences between the cell walls of Gram-positive and Gram-negative bacteria. These results can be used for the engineering of other recombinant proteins for secretory production in E. coli.

\section{Experimental procedures}

\section{Bacterial strains and plasmids}

Bacillus subtilis strain 168 (ATCC23857) was obtained from the American Type Culture Collection. The bacteria were grown on NA agar at $30^{\circ} \mathrm{C}$. E. coli DH5 $\alpha$ (Life Technologies, USA) and TOP10 (Invitrogen, USA) were used as a cloning and expression host, respectively. The plasmid pMY202, which was used for cloning and expression of the B. subtilis chitosanase gene, was modified from pFLAG-CTS (Sigma, USA) by replacing the multiple cloning sites (MCS) between HindIII and SalI of the pFLAG-CTS in a way that the SalI was destroyed after ligation (Yamabhai et al. 2011). The map of pMY202 can be found in Additional file 7: S1.

\section{Substrate}

Low molecular weight Csn [product number 448869 (75-85 \% DDA)] was purchased from Sigma-Aldrich and soluble chitosan $(10 \mathrm{mg} / \mathrm{mL})$ was prepared by dissolving $10 \mathrm{~g}$ of chitosan in $400 \mathrm{~mL}$ of distilled water and $90 \mathrm{~mL}$ of $1 \mathrm{M}$ acetic acid. The Csn solution was adjusted to $\mathrm{pH}$ 5.5 with $1 \mathrm{M}$ sodium acetate to a final volume of $1 \mathrm{~L}$ with distilled water.

\section{Molecular cloning}

The genes encoding Csn from B. subtilis 168 containing the native signal peptide (Nat-Csn) or the mature enzyme fused with the E. coli OmpA signal peptide (OmpA-Csn) were cloned by PCR-based methods into the pMY202 vector (Additional file 7: S1), according to a previously published protocol (Songsiriritthigul et al. 2010). The primers were designed from the published database of the DNA sequence of the Csn gene of B. subtilis 168 (NCBI accession number: NC_000964 REGION: complement (2747984..2748817). The primers, B.subCsnNdeIFw: $5^{\prime}$ CTG TGC CAT ATG AAA ATC AGT ATG CAA AAA GCA GAT TTT TGG $3^{\prime}$ and B.subCsnBamHIRv: 5' GCA CAG GGA TCC TTT GAT TAC AAA ATT ACC GTA CTC GTT TGA AC $3^{\prime}$ were used for PCR amplification of the B. subtilis Csn gene containing the native signal peptide (Nat-Csn). The PCR products were cut with $N d$ eI and BglII and cloned into NdeI and BglII sites on the pMY202 plasmid. For the construction of the recombinant chitosanase gene, of which the native signal peptide was replaced with the E. coli OmpA signal peptide (OmpA-Csn), primers B.subCsnOmpAHindIIIFw: $5^{\prime}$ CTGTGCAAG CTT CGG CGG GAC TGA ATA AAG ATC AAA AGC3' and B.subCsnBamHIRv: 5' GCA CAG GGA TCC TTT GAT TAC AAA ATT ACC GTA CTC GTT TGA AC $3^{\prime}$ were used in the PCR reaction. The PCR products were cut with HindIII and BamHI and ligated into a pMY202 vector that had been digested with the same enzymes. The recombinant constructs of 
B. subtilis Csn containing either the native or the OmpA signal peptide were designated Nat-Csn/pMY202 and OmpA-Csn/pMY202, respectively. The integrity of the constructs was confirmed by automated DNA sequencing (Macrogen, Korea).

\section{Expression and preparation of recombinant chitosanases from various compartments}

Four colonies of freshly transformed E. coli TOP10 harboring appropriate constructs were transferred into $20 \mathrm{~mL}$ Luria-Bertani (LB) broth containing $100 \mu \mathrm{g} / \mathrm{mL}$ ampicillin (LB-Amp) and grown overnight at $37^{\circ} \mathrm{C}$. Then, $2 \%$ of the overnight cultures were added into $200 \mathrm{~mL}$ LB-Amp broth and grown at $37^{\circ} \mathrm{C}$ with shaking until an optical density at $600 \mathrm{~nm}\left(\mathrm{OD}_{600}\right)$ of $0.6-0.7$ was reached. Isopropyl- $\beta$-D-thiogalactopyranoside (IPTG) was added into the culture broth to a final concentration of $0.1 \mathrm{mM}$ (for purification as shown in Fig. 3) or $0.5 \mathrm{mM}$ (for determination of enzyme activities in various compartments as reported in Table 1), and the incubation was continued at ambient temperature $\left(27-28{ }^{\circ} \mathrm{C}\right)$ with shaking. Fifty $\mathrm{mL}$ of culture was collected after induction for 4 and $20 \mathrm{~h}$ and then centrifuged at $4000 \times g$ for $30 \mathrm{~min}$ at $4{ }^{\circ} \mathrm{C}$. Preparation of periplasmic extract and cell lysate (cytosolic fraction) was done as previously described (Yamabhai et al. 2008).

\section{SDS-PAGE}

Denaturing sodium dodecylsulfate-polyacrylamide gel electrophoresis (SDS-PAGE) was performed according to the method of Laemmli (Laemmli 1970). Protein bands were stained by Coomassie brilliant blue R-250. Protein ladder $(10-200 \mathrm{kDa})$ was purchased from Fermentas (St. Leon, Germany) and Bio-Rad. The protein samples were briefly heated ( $3 \mathrm{~min}$ ) in loading buffer (Laemmli buffer) with reducing agent $(100 \mathrm{mM} \beta$-mercaptoethanol) at $100{ }^{\circ} \mathrm{C}$, using a heat block before loading onto the gel.

\section{Enzyme activity assay on agar plates}

The activity of recombinant Csn was assayed on LB agar plates containing $100 \mu \mathrm{g} / \mathrm{mL}$ ampicillin and $0.1 \%(\mathrm{w} / \mathrm{v})$ of low MW chitosan. Various concentrations of IPTG (0, $0.1,0.5 \mathrm{mM}$ ) were spread onto the plate before freshly transformed cells were spotted onto the plates and incubated at $37^{\circ} \mathrm{C}$. Hydrolytic clear zones were observed and the diameters of the clear zones were measured at various time points. The experiments were done in triplicate. The average diameters with SD values were reported.

\section{Chitosanase activity assay}

Standard Csn activity was determined using the 3,5-dinitrosalicylic acid (DNS) method (Miller 1959). The reaction mixture consisted of $40 \mu \mathrm{L}$ of enzyme $(0.4 \mu \mathrm{g})$ and
$160 \mu \mathrm{L}$ of $0.5 \%(\mathrm{w} / \mathrm{v})$ of soluble chitosan in $200 \mathrm{mM}$ sodium acetate buffer, $\mathrm{pH} 5.5$. The reaction was incubated in a Thermomixer Comfort (Eppendorf AG, Hamburg, Germany) at $50{ }^{\circ} \mathrm{C}$ for $5 \mathrm{~min}$, with mixing at $900 \mathrm{rpm}$. The reaction was stopped by adding $200 \mu \mathrm{L}$ of DNS solution and centrifuged at $12,000 \times g$ for $5 \mathrm{~min}$ to precipitate the remaining chitosan. Then, the color was developed by heating at $100{ }^{\circ} \mathrm{C}$ for $20 \mathrm{~min}$ and cooled on ice. The concentration of reducing sugar in the supernatant was determined by measuring the OD at $540 \mathrm{~nm}$, using D-glucosamine $(1-5 \mu \mathrm{mol} / \mathrm{mL})$ as a standard. One unit of Csn activity was defined as the amount of enzyme that released $1 \mu \mathrm{mol}$ of $\mathrm{D}$-glucosamine per minute under standard assay conditions. The experiments were performed in duplicate.

\section{Purification of recombinant chitosanase}

Recombinant $10 \times$ His-tagged Csn proteins were purified from culture supernatant and cell lysate by immobilized metal affinity chromatography (IMAC), using Ni-NTA agarose (Qiagen, Germany) as previously described (Juajun et al. 2011). The enzyme was eluted with $250 \mathrm{mM} \mathrm{imi-}$ dazole. The eluted enzyme was passed through Vivaspin6 columns ( $\mathrm{M}_{\mathrm{r}}$ cut-off $10 \mathrm{kDa}$; GE Healthcare, Sweden) to remove imidazole and concentrate the protein. The purified enzyme was stored at $4{ }^{\circ} \mathrm{C}$ until further use. Protein concentrations were determined by the method of Bradford (Bradford 1976) using a Bio-Rad protein assay kit and bovine serum albumin (BSA) as the standard. The standard calibration curve was constructed from 0.05 to $0.5 \mathrm{mg} / \mathrm{mL}$ BSA.

\section{$\mathrm{N}$-terminal sequencing}

$1.25 \mu \mathrm{g}$ samples of purified OmpA-Csn and Nat-Csn were separated by SDS-PAGE on $15 \%$ gels and electroblotted onto polyvinylidenedifluoride (PVDF) membrane (Bio-Rad, USA) in $50 \mathrm{mM}$ borate buffer containing $10 \%(\mathrm{v} / \mathrm{v})$ methanol, $\mathrm{pH}$ 9. After blotting, the membrane was stained with Coomassie blue for $3 \mathrm{~min}$, followed by destaining of the membrane with destaining solution (40\% (v/v) methanol and $10 \%(\mathrm{v} / \mathrm{v})$ acetic acid). N-terminal sequences were commercially analyzed using Edman degradation on an Applied Biosystems Procise 492 protein sequencer (Protein Micro-Analysis Facility, Medical University of Innsbruck, Austria).

\section{MALDI-TOF MS}

Protein samples were loaded into Zeba ${ }^{\mathrm{TM}}$ Spin Desalting Columns (Thermo Scientific Inc., USA) pre-equilibrated with water. The columns were centrifuged at $1500 \mathrm{rpm}$ for $2 \mathrm{~min}$ and the desalted fraction was precipitated overnight with 2 volumes of cold acetone at $-20{ }^{\circ} \mathrm{C}$ After centrifugation at $12,000 \mathrm{rpm}$ for $15 \mathrm{~min}$, the protein 
pellet was resuspended in $0.1 \% \mathrm{TFA} / 50 \% \mathrm{ACN}$ to a final concentration of $10 \mu \mathrm{g} / \mu \mathrm{L}$. The protein was mixed with MALDI matrix solution $(10 \mathrm{mg}$ sinapinic acid in $1 \mathrm{~mL}$ of $50 \%$ acetonitrile containing $0.1 \%$ trifluoroacetic acid), directly spotted onto the MALDI target (MTP 384 ground steel, Bruker Daltonik, $\mathrm{GmbH}$ ), and allowed to dry at room temperature. MALDI-TOF MS spectra were collected using Ultraflex III TOF/TOF (Bruker Daltonik, $\mathrm{GmbH}$ ) in linear positive mode with a mass range of 5000-100,000 Da. Five hundred shots were accumulated with a $200-\mathrm{Hz}$ laser for each sample. MS spectra were analyzed by FlexAnalysis software (Bruker Daltonik, $\mathrm{GmbH}$ ). Bovine insulin, equine cytochrome $\mathrm{C}$ and equine apomyoglobin were used as external protein calibrations.

\section{Additional files}

\author{
Additional file 1: S1. Clear Zones from an agar plate assay. \\ Additional file 2: S7. Purification table. \\ Additional file 3: S2. Summary of N-terminal sequence analysis of \\ secreted Nat-Csn.
}

Additional file 4: S3. Summary of $\mathrm{N}$-terminal sequence analysis of secreted OmpA-Csn.

Additional file 5: S4. Raw data of $\mathrm{N}$-terminal sequence analysis of secreted Nat-Csn.

Additional file 6: S5. Raw data of N-terminal sequence analysis of secreted Nat-Csn.

Additional file 7: S1. Map of pMY202 expression vector. The pMY202 vector was used for the expression of the Bacillus chitosanase gene. This plasmid contained the E. coli OmpA signal peptide (blue) upstream from the multiple cloning site (MCS). Protein expression was under the control of a tac promoter. The vector contained an ampicillin resistance gene and a C-terminal 10x-histidine tag (red) to facilitate affinity purification. The plasmid used an origin of replication (ori) from pBR322, which has a lowcopy number (15-20 plasmids per cell).

\section{Authors' contributions}

PP performed enzyme expression and analysis, and prepared enzymes for $\mathrm{N}$-terminal sequencing. CS helped characterize the enzyme and drafted the manuscript. DH co-designed the experiments and edited the manuscript. SR performed MALDI-TOF MS analysis. NB helped designed the experiment, discuss and edit the manuscript. MY conceived of the study and wrote the manuscript. All authors read and approved the final manuscript.

\section{Author details}

${ }^{1}$ Molecular Biotechnology Laboratory, School of Biotechnology, Institute of Agricultural Technology, Suranaree University of Technology (SUT), 111 University Avenue, Meung District, Nakhon Ratchasima 30000, Thailand. ${ }^{2}$ Synchrotron Light Research Institute (Public Organization), Nakhon Ratchasima, Thailand. ${ }^{3}$ Food Biotechnology Laboratory, BOKU - University of National Resources and Life Sciences, Vienna, Austria. ${ }^{4}$ Genome Institute, National Center for Genetic Engineering and Biotechnology, Pathumthani, Thailand.

\section{Acknowledgements}

This work was supported by the Higher Education Research Promotion and National Research University (NRU) Project of Thailand, Office of Higher Education Commission. It is the outcome of the collaboration according to the MoU between SUT and BOKU.

\section{Competing interests}

The authors declare that they have no competing interests.
Received: 10 April 2016 Accepted: 21 July 2016

Published online: 28 July 2016

\section{References}

Albiniak AM, Matos CF, Branston SD, Freedman RB, Keshavarz-Moore E, Robinson C (2013) High-level secretion of a recombinant protein to the culture medium with a Bacillus subtilis twin-arginine translocation system in Escherichia coli. FEBS J 280(16):3810-3821

Andersson H, von Heijne G (1991) A 30-residue-long "export initiation domain" adjacent to the signal sequence is critical for protein translocation across the inner membrane of Escherichia coli. Proc Natl Acad Sci U S A 88(21):9751-9754

Bendtsen JD, Nielsen H, von Heijne G, Brunak S (2004) Improved prediction of signal peptides: SignalP 3.0. J Mol Biol 340(4):783-795

Bradford MM (1976) A rapid and sensitive method for the quantitation of microgram quantities of protein utilizing the principle of protein-dye binding. Anal Biochem 72:248-254

Choi JH, Lee SY (2004) Secretory and extracellular production of recombinant proteins using Escherichia coli. Appl Microbiol Biotechnol 64(5):625-635

de Boer HA, Comstock LJ, Vasser M (1983) The tac promoter: a functional hybrid derived from the trp and lac promoters. Proc Natl Acad Sci USA 80(1):21-25

de Keyzer J, van der Does C, Driessen AJ (2003) The bacterial translocase: a dynamic protein channel complex. Cell Mol Life Sci 60(10):2034-2052

Degering C, Eggert T, Puls M, Bongaerts J, Evers S, Maurer KH, Jaeger KE (2010) Optimization of protease secretion in Bacillus subtilis and Bacillus licheniformis by screening of homologous and heterologous signal peptides. Appl Environ Microbiol 76(19):6370-6376

Driessen AJ, Manting EH, van der Does C (2001) The structural basis of protein targeting and translocation in bacteria. Nat Struct Biol 8(6):492-498

Gao D, Wang S, Li H, Yu H, Qi Q (2015) Identification of a heterologous cellulase and its $\mathrm{N}$-terminus that can guide recombinant proteins out of Escherichia coli. Microb Cell Fact 14:49

Juajun O, Nguyen TH, Maischberger T, Iqbal S, Haltrich D, Yamabhai M (2011) Cloning, purification, and characterization of beta-galactosidase from Bacillus licheniformis DSM 13. Appl Microbiol Biotechnol 89(3):645-654

Laemmli UK (1970) Cleavage of structural proteins during the assembly of the head of bacteriophage T4. Nature 227(5259):680-685

Mathiesen G, Sveen A, Piard JC, Axelsson L, Eijsink VG (2008) Heterologous protein secretion by Lactobacillus plantarum using homologous signal peptides. J Appl Microbiol 105(1):215-226

Mergulhao FJ, Summers DK, Monteiro GA (2005) Recombinant protein secretion in Escherichia coli. Biotechnol Adv 23(3):177-202

Miller GL (1959) Use of dinitrosalicylic acid reagent for determination of reducing sugar. Anal Chem 31(3):426-428

Muller M, Koch HG, Beck K, Schafer U (2001) Protein traffic in bacteria: multiple routes from the ribosome to and across the membrane. Prog Nucleic Acid Res Mol Biol 66:107-157

Nakamura K, Fujita Y, Itoh Y, Yamane K (1989) Modification of length, hydrophobic properties and electric charge of Bacillus subtilis alphaamylase signal peptide and their different effects on the production of secretory proteins in B. subtilis and Escherichia coli cells. Mol Gen Genet 216(1):1-9

Paetzel M (2014) Structure and mechanism of Escherichia coli type I signal peptidase. Biochim Biophys Acta 1843(8):1497-1508

Pechsrichuang P, Yoohat K, Yamabhai M (2013) Production of recombinant Bacillus subtilis chitosanase, suitable for biosynthesis of chitosan-oligosaccharides. Bioresour Technol 127:407-414

Puigbo P, Guzman E, Romeu A, Garcia-Vallve S (2007) OPTIMIZER: a web server for optimizing the codon usage of DNA sequences. Nucleic Acids Res 35:W126-W131

Rinas U, Hoffmann F (2004) Selective leakage of host-cell proteins during highcell-density cultivation of recombinant and non-recombinant Escherichia coli. Biotechnol Prog 20(3):679-687

Songsiriritthigul C, Lapboonrueng S, Pechsrichuang P, Pesatcha P, Yamabhai M (2010) Expression and characterization of Bacillus licheniformis chitinase 
(ChiA), suitable for bioconversion of chitin waste. Bioresour Technol 101(11):4096-4103

van Roosmalen ML, Geukens N, Jongbloed JD, Tjalsma H, Dubois JY, Bron S, van Dijl JM, Anne J (2004) Type I signal peptidases of Gram-positive bacteria. Biochim Biophys Acta 1694(1-3):279-297

Yamabhai M, Emrat S, Sukasem S, Pesatcha P, Jaruseranee N, Buranabanyat B (2008) Secretion of recombinant Bacillus hydrolytic enzymes using Escherichia coli expression systems. J Biotechnol 133(1):50-57 Yamabhai M, Buranabanyat B, Jaruseranee N, Songsiriritthigul C (2011) Efficient $E$. coli expression systems for the production of recombinant beta-mannanases and other bacterial extracellular enzymes. Bioeng Bugs 2(1):45-49

Yuan J, Zweers JC, van Dij JM, Dalbey RE (2010) Protein transport across and into cell membranes in bacteria and archaea. Cell Mol Life Sci 67(2):179-199

Zhang Z, Henzel WJ (2004) Signal peptide prediction based on analysis of experimentally verified cleavage sites. Protein Sci 13(10):2819-2824

Zhou Z, Zhao S, Wang S, Li X, Su L, Ma Y, Li J, Song J (2015) Extracellular overexpression of chitosanase from Bacillus sp. TS in Escherichia coli. Appl Biochem Biotechnol 175(7):3271-3286

\section{Submit your manuscript to a SpringerOpen ${ }^{\circ}$ journal and benefit from:}

- Convenient online submission

\section{- Rigorous peer review}

- Immediate publication on acceptance

- Open access: articles freely available online

- High visibility within the field

- Retaining the copyright to your article 